\title{
Analysis of Women Characters in Miranda Stories
}

\author{
Wang Ru \\ Foreign Languages School, Jiangxi Normal University, Jiangxi Province, China
}

\begin{abstract}
Katherine Anne Porter was awarded Pulitzer Prize for Fiction and National Book Award for her most important works The Collection of Short Stories which include 27 short stories, nine of which are Miranda stories consisting of Old Mortality, The Old Order and Pale Horse,Pale Rider. Miranda stories give an account of the life experience of three generations of females in Miranda family, including Miranda's grandma, aunt Amy and Eva and Miranda herself. Combined with the background of Potter's life and feminist movement in the United States, this paper analyzed the existence status and the images of female characters in Miranda family, and explored the process of female consciousness, which will help comprehensively understand Potter's works and her female's awakening.
\end{abstract}

Keywords: Katherine anne porter; Miranda stories; Feminine conscious.

(9) (1) CC BY: Creative Commons Attribution License 4.0

\section{Introduction}

\subsection{Katherine Anne Porter and Miranda Stories}

Katherine Anne Porter is one of the most famous modern short fiction writers in America. Throughout her 90 years' long life, Porter wrote 27 novels. Most of the novel materials were taken from her own experiences in South America, Mexico and Europe. Potter explored special and subtle meaning of life in those experiences, each work contains profound implication. Her novels often concern serious subjects such as religion,politics,death,nature of evil, self-delusion, and the relation between man and woman.Miranda remains Porter's most popular protagonist, and the Miranda stories have been viewed as attempts by Porter to come to terms with the repressed Southern world of her childhood.

Miranda stories consist of nine stories, including Old Mortality, and Pale Horse, Pale Rider and The Old Order, which were made up of the short stories, The Source, The Witness, The grave, The Last Leaf, The Fig Tree and The Grave. These Miranda stories are closely rooted in Porter's personal experience from her childhood to her adulthood. These stories recorded Porter's development from an innocent childhood to a mature female writer. Miranda, Katherine Anne Porter's best known character and central figure in the stories generally referred to by her name, comes from a long line of ancestors. And characters belong to different generations, who form a chorus of voices unanimous in their obsession with the past: Sophia Jane, Amy And Miranda form different attitudes to the identity as females in the patriarch southern family.

\section{Grandma: From Compliance to Resistance}

Among the short stories of Porter, The Old Order was one of the most popular story series consisting of seven stories. And Sophia Jane, Miranda's grandma was one of the most important female characters, who was a defender of the old order and firmly controller in the whole house. Grown up in a rich family, Sophia Jane was firmly under the control of her patriarchal father and was destined to be locked in the culture that men dominated women. She had to marry her cousin, who was feckless and lack of aims, nearly destroying the whole family because of his reckless investment. Forced by the poverty-stricken situation, she had to play the role of head of the big family since her husband died. However, She never lived a life according to her own heart, while she had to give in to her gender identity which she had been accustomed to. When her husband died, she played both feminine role and male role, but she just did the latter out of living necessity.

Compared with the view of Nance (1965) that Sophia Jane was a woman who bravely went against the patriarchal codes for the reason that she cut timber and plowed fields like a man, I think Sophia Jane just separately fulfilled the feminine role and the masculine role rather than violated the expectation for the women. Both roles she played was in accordance with the ritual of discipline in society. When she played the role of the feminine, she enjoyed the work for a woman, having passion for cutting scraps of the family finery, dressing tables, sitting under the mingled trees for a good glance on what happened around them (It was a domestic strategy for them).

In fact, Sophia Jane perfectly did what a woman should do at home in patriarchal society. While playing the role of patriarchal masculine as her husband died in her middle age, she would strictly abide by the codes of patriarchal culture. Never for a moment did she think about exert her rights as a woman.

"She lived her youth so, without once giving herself away; not until she was in middle age, her husband dead, her property dispersed, and she found herself with a houseful of children, making a new life for them in another place, with all the responsibilities of a man but with none of the privileges, did she finally emerge into something like an honest life: and yet, she was passionately 
honest. She had never been anything else."(The collected stories of Katherine Anne Porter, (Porter, 1965)

Sophia did a man's work largely out of the responsibility for supporting the whole family. So she had to build a house to shelter and got the fields fenced in and crops planted. Actually she had no choice because her sons were still too young to be independent from her. Although she started to fulfill the responsibility of a man in patriarchal culture, she never had a moment to enjoy the privilege. As the narrator says, Sophia Jane was just too honest or in other words was willing to yield to the codes of patriarchal culture without any idea of fleeing from the oppressed situation. There is a very typical scene showing Sophia Jane's double gender roles in her family.

\section{Aunts: Eager for Freedom}

Compared with Sophia Jane who was an active supporter of patriarchal ideologies and the legend of family history, other female characters Katherine Anne Porter described in her fictions like Amy and Eva had obtained desire for freedom and attempted to flee away from the suppressed tradition to seek themselves. Having been imprisoned in the southern family for a long time and influenced by its culture, they were indecisive to change their situation. On the one hand, they yearned for a different life which might totally violate the order the society demanded, on the other hand, they were constraint by the consciousness they were inculcated.

\subsection{Amy: A Struggling Southern Lady}

Amy, who was the daughter of Sophia Jane and aunt of Miranda, was brought up in the traditional southern family at the turn of century and became the model of Southern fair lady. She was constantly praised and remembered by Miranda's grandma, father and the relatives in her big family. Almost every member of the old generations in her family thought she was so beautiful, charming and graceful that there were so many young men fall in love with her on seeing her. In people's memory, she was a good horse rider with the style of pure Spanish and a excellent dancer whose waltzer was light, smooth and delicate. Her romantic story with Gabriel was a favorite tale in Miranda family, in which Amy and Gabriel were regarded an ideal couple. However, no matter how great she was looked in other people's eyes. Amy's life was full of helplessness and struggle. She seemed never really happy in her life and committed suicide. Actually she was the oppressed of the patriarchy. Had she been mindless, she would have spent her life with Gabriel happily and made her family proud. Unfortunately, she was such a insightful girl that she couldn't really violate her own will and live her whole life with Gabriel willingly.

In the first part of "Old Mortality, Amy was the heroine of story, but Amy never spoke for herself. This made Amy essentially a silent figure. She was destined to be a woman misunderstood and seen as people not of the same clan because of the lack of narrative voice in the construction of her image. Born in a patriarchal family, Amy was faced with too many rules and principles in daily life. But for Amy, she always did something incompatible with the patriarchal culture. In a big gay fancy-dress ball, Amy dressed herself up as a Dresden-china copy with low-laced bodice, short skirts and green slippers. Amy's father felt outrage when he found his daughter white ankle shining, bosom exposed and spots of paint on her cheek. To him, Amy's behavior was disgraceful and bawdy and believed that there were all the difference in the world. However, Amy just smiled and comforted his father by cleaning face, filling in the bodice with lace. But when she left home and appeared in the ball, the lace disappeared from her bodice,skirt shorter and spots on the cheek like pomegranates. She didn't want to please anyone and just wanted to be a free bird. Gabriel was a loyal suitor of Amy and also was believed the prefect fiance for Amy.

As the heroine of the scandal, Amy would obviously showed her expectation for freedom and coquetry rather than obedience and marriage without love, but she is not strong enough physically or psychically to abandon her appointed gender role for the rather dubious one of an unmarried flirt.The influence of the scandal on the family was great. Amy confronted too much psychological pressure and strict patriarchal principles, so she had to compromised with the social rituals. In order to eliminate the negative influence of the scandal on her family, she was bothered with struggle. Amy rebelled against the patriarchal ideology through extreme way-death. Superficially, it is kind of tragedy.

"She lives again who suffered life.

Then suffered death, and now set free

A singing angel, she forgets

The griefs of old mortality."(Porter,181)

Amy's death highlights her determination to rebel against the patriarchal ideology and her desire for freedom. However, it also reflects the fact that she was ironically defeated by patriarchal idea of gender, because she was still defined by the value of patriarchal idea of gender and manipulated her beauty as power to dominate Gabriel.

\subsection{Eva: A Desperate Feminist}

Eva Parrington was a pretty unremarkable female figure in Old Mortality, who was the cousin of Amy. Compared with the perfect image of Amy admired by the old people in the family, Eva was was chinless with two enormous teeth. She was labeled as old maid and ugly duck in her family. Ironically, Eva's mother was a beautiful woman and surrounded by many men. She never showed her natural love to her daughter and even counted herself lucky by saying that "It's lucky for me my daughter is an old maid. She is not so apt to make a grandmother of me" (Porter, 178). Though Eva always silently sat in corners watching her mother dancing with other men, yet she would dance prettily and smile while her mother was away. She was so long for attracting the attention of the boys in the ball through her dances. Unfortunately, her efforts didn't paid off. 
To confront the patriarchal ideology, Eva sacrificed her chair at Seminary and was jailed for three times. For Eva, it was some kind way of venting her frustration to the patriarchal ideology and showed her value. As the peer of Amy, Eva undertook too much psychical and psychological pressure. Amy laughed at her chin by saying that Eva would not have husband if she didn't look out and held her chin up. Having been long repressed by Amy and despised, Eva hated Amy and even twisted her psychology. On a train to attend Gabriel' s funeral, Eva occasionally met Miranda and she talked about the image of Amy in her mind, who was so totally different from the angel Miranda learned about from her father and grandma. In Eva's eye, Amy was no so loved by everyone, but a spoiled daring who always did things as she liked and made other suffer from what she did. Obviously, there's some kind of jealousy in Eva's words, for whose whole life was looked down and never had her behavior been praised. Eva even showed her faith in the impurity of Amy's behavior and doubt her "Virtuous".

"What I ask myself, what I ask myself over and over again,...is, what connection did this man Raymond from Calcasieu have with Amy's sudden marriage to Gabriel, and what did Amy do to make away with herself so soon afterward? For mark my words, child, Amy wasn't so ill as all that. She'd been flying around for years after the doctors said her lungs were weak. Amy did away with herself to escape some disgrace, some exposure that she faced" (Porter, 1965).

Eva believed that Amy had some scandals with Raymond, which was far more disgraceful than Miranda knew. She often said that she heard other said that actually the reason why Harry shot Raymond was that Amy was persuaded to elope with Raymond on the ball. Eva liked to referred to the gossip about the scandal many people talked regardless of its truth but as the proof to prove the real image of Amy fit to her thoughts.

In a word, Eva envied Amy and hated her behavior so much. Though she took active part in voting women, her ideas had been boxed into the traditional patriarchal ideology. Her hostile attitude to the beauty, the purity and freedom that Amy tirelessly pursued; her scorn on the scandal that Amy on the dress ball; her belief that the girls actively attending the parties was just for sex; her criticism on Miranda when she knew that Miranda eloped with a man in school; her self-abasement when she thought of her ugly chin and her complaint that her whole life was destroyed by her chin. All these ideas were part of patriarchal ideology. As an advocate of women voting, her motivations were worth doubting.

\section{Young Miranda: From Innocence to Independence}

The character of Miranda ran through the stories the dissertation discussed, though she was not always the heroine. However, the development of the Miranda was hidden in the stories. As the narrator of these stories, Miranda told the stories of her families and her personal life in the way of remembering. From a little girl who was still held by her families to a mature young woman, the stories continuously showed us the growth journey of Miranda under the great influence of her patriarchal family background. Katherine Anne Porter devotes large space to shaping the character Miranda who was the autobiographical figure of Porter herself.

Like Porter, Miranda went through a long experience from a naive young girl to mature woman. She escaped from her depressing family and married a young man blindly. But she still could not bear the family life as a wife and again escaped from the situation. She also chose reporter as her job and tirelessly sought truth and selfindependence. This kind of hardship for Miranda was just like the long journey of a phoenix from the ashes. From an innocent girl, Miranda grow into a independent woman who could do things according to her own feelings and found her own ego finally.

"She even peeped down between the wide crevices of the piled-up plank seats, where she was astonished to see odd-looking, roughly dressed little boys peeping up from the dust below. . She looked squarely into the eyes of one, who returned her a look so peculiar she gazed and gazed, trying to understand it. It was a bold grinning stare without any kind of friendliness in it...As she gazed he nudged the little boy next to him, whispered, and the second little boy caught her eye... 'Dicey, what are those little boys doing down there?' 'Down where?'asked Dicey, but she seemed to know already, for she bent over and looked through the crevice, drew her knees together and her skirts around her, and said severely: 'You jus mind yo' own business and stop throwin' yo' legs around ..." " (Porter, 1965).

The gazes between Miranda and the boys were so different. The former was from the curiosity of an innocent girl, the latter represented the sexual hint of the boys. The following reflections of these boys further hurt the little girls feeling. The boy's friendless stare and whisper made the young Miranda totally under the observance of the boys and somewhat became the prey. All these was to blame to her throwing her leg around. This kind of experience first shocked the young Miranda who for a long time was surrounded by her families and didn't really understand the meaning of the gaze from a boy. The effect on Miranda is to suddenly become aware of masculine attention that place her in a position of vulnerability thereby making her more apt to accept the traditional patriarchal roles that privileges male over female.

Miranda' s awaking and disillusionment came when one Saturday her father went to the convent and took Miranda and her sister Maria to see a horse race, in which their uncle Gabriel was also one of the horse riders in the race who was also one of the most romantic man they had learned since they were very young. It was a release for them who had long been hedged in convent as well as the chance for them to free from false notions on uncle Gabriel and the romantic story between Gabriel and Amy.

Having witnessed the passive acceptance of patriarchal culture and a paradoxical rebellion against it, Miranda came to awake from the illusion in the family and decided to refuse to accept her role in the family she was assigned. She hated the presence of these aliens who lectured and admonished her and those who loved her in an extreme way 
and denied her right to see the world in her own eye. She wondered where her own people and her own time are. Looking forward to living her own life full of all kinds of possibilities, Miranda began to take control of her own life and put all her faith in the future. "but there is my own life to come yet, she thought, my own life now and beyond... she assured herself silently, making a promise to herself in her hopefulness, her ignorance" (Porter, 1965).

At the end of Old Morality, Miranda grew up and married, but she was still was at a crossing road. Though she had got married to escape the complex family bonds which smothered her in love and hatred, she was not really happy and even found herself again stuck in the domestic affairs of the wife and motherhood as well as all kinds of rules assigned to her by the patriarchal ideologies. On the journey to the funeral of Gabriel, her reunion with cousin Eva, a feminist who superficially freed from the traditional order of woman but was no more than a desperate maid who longed for being a southern belle helped Miranda realize what kind of position she was in the family and that Eva was never the kind of people she would be. After Miranda met Eva, Miranda was conscious of the necessity that she would give up the marriage that she had expected that it would bring her happiness and shake off the gender restraints, and decided to seek for the unknown future.

As the story moved on, we see that Miranda had became a totally new woman who was repelled according to her grandma criteria about modern woman who fought for autonomy and independence in economy and ideology. It was worth mentioning that Miranda was a reporter in a newspaper, because this job enabled her to make discoveries by her own eyes and wrote according to her own thoughts. Apparently, Miranda made up her mind to get rid of the past and was not the innocent girl who looked at the world with wonder, but a mature woman looked at the world based on her own judgment.

\section{Conclusion}

This paper explores the feminist consciousness of Katherine Anne Porter through her Miranda stories. There are three typical female images exemplified by Sophia Jane, Aunt Amy and Eva, and Miranda, respectively representing different stance on female consciousness in the process of American feminist development.

Then carefully comparing Katherine Anne Porter's life experience and the history background with Miranda's stories, we may see that the fictions of Miranda stories were full of the shadow of Porter herself. Katherine Anne Porter was also born in a southern family and escaped it when she was 16 years old in order to shake herself off her tradition family. By great efforts and talents, Porter obtained what she needed and desired, which was such an unusual things for the women of her times. As a member of the wave of feminist movement, Porter expressed her aspiration for the liberation of women by her pen in her own way. Although Katherine Anne Porter didn't express her opinion on feminist movement publicly, her consciousness of feminist was obvious if we inspect her life experience and her works. Nowadays, women's rights have been greatly emphasized,but it didn't means that women in the world are really share equal rights with men. Thus there are many things remaining to do the further promote female liberation.

\section{References}

Nance, W. L. (1965). Katherine anne porter and the art of rejection. Chapel Hill: U of North Carolina P. Porter, K. A. (1965). The collected stories of katherine anne porter. Harcourt: New York.

\section{Bibliography}

Bennett, P. (1992). The texas legacy of katherine anne porter by james t. F. Tanner. The Southwestern Historical Quarterly, 1992(1): 142-43.

Busby, M. and Dick, H. (2001). From texas to the world and back:Essays on the journeys of katherine anne porter. Fart Worth, TX: TCU P.

Carson, B. H. (1977). Winning: Katherine anne porter's women, the authority of experience: Essays in feminist criticism. Ed. Arlyn diamond and lee r.Edwards. Amherst: U of Massachusetts P. 239-56.

Cheatham, G. (1989). Death and repetition in porter's miranda stories. American Literature: 610-24.

Erdin, E. (1990). The ring or the dove: The new woman in katherin anne porter's fiction."women and war: The changing status of american from the 1930s to 1950s. Eds. Maria diedrich and dorothea fischer-hornung. New York: Berg. 51-67.

Eric, R. G. (2003). Death and katherine anne porter:A reading of the long stories. Oklahoma State University.

Freud, S. (1955). Beyond the Pleasure Principle. The standard edition of the complete works of sigmund freud. Hogarth: London.

Freud, S. (1991). The ego and the id ",on meta-psychology:The theory of psychoanalysis. Penguin Books.

Givner, J. (1982). Katherine anne porter: A life. Simon and Schuster: New York.

Graham, D. (1999). Katherine anne porter's jounery from texas to the world. Southwest Review, (1): 148.

Hankinson, S. (1997). Politics,pacifism, and feminist liberation in the works of katherine anne porter. Indiana University of Pennsyvania.

Hartley, L. and George, C. (1969). Katherine anne porter: A critical symposium. Athens, GA: U of Georgia P.

Mooney, B. J. (1962). The fiction and criticism of katherine anne porter. Pittsburgh, PA: U of Pittsburgh P.:

Stout, J. P. (1995). Katherine anne porter: A sense of the times. Charlottesville, VA: UP of Virginia.

Unrue, D. H. (1985). Truth and vision in katherine anne porter's fiction. Athens, GA: U of Georgia P. 